\title{
Effects of different fatty acid supplementation on body weight and haematobiochemical parameters in rat
}

\author{
Rahman MA ${ }^{1}$, Jahan $\mathrm{M}^{2 *}$, Karmaker $\mathrm{S}^{1}$ and Islam $\mathrm{MK}^{1}$ \\ ${ }^{I}$ Department of Physiology, Faculty of Veterinary Science, Bangladesh Agricultural University, Mymensingh- \\ 2202, ${ }^{2}$ Department of Animal Husbandry and Veterinary Science, Rajshahi University, Rajshahi- 6205.
}

[Received: January 24, Accepted: March 28, 2012]

\begin{abstract}
The effects of some selected fatty acids supplement on hematobiochemical parameters were studied in rat. A total of twenty rats were randomly assigned into four groups. Group A was considered as control and fed with rat pellet. Group B was treated with $20 \mathrm{mg}$ Soybean oil $/ \mathrm{kg}$ feed, group C with $20 \mathrm{mg}$ Mustard oil/ $\mathrm{kg}$ feed and group D with $20 \mathrm{mg}$ Ghee $/ \mathrm{kg}$ feed. The mean body weight of group B, C and D of 2nd and $3^{\text {rd }}$ observation (30 and 60 days, respectively) was significantly ( $P>0.01$ ) higher compared to group A (Control). The highest body weight was observed in $3^{\text {rd }}$ observation and it was $185.00 \pm 2.76 \mathrm{~g}$ in group $\mathrm{D}$ and the lowest was in control group. TLC value of group D increased significantly $(\mathrm{P}<0.01)$ compared to control and was also found higher for group of B and C than that of control. Similar results were found for PCV value. DLC value was significant for none of the groups. The serum cholesterol level of group D increased significantly $(\mathrm{P}<0.01)$ but it was also found higher for the groups B and C than that of control. Similar results were found for blood glucose level and Serum Glutamic Pyruvic Transaminase (SGPT) where the values of group D increased significantly $(\mathrm{P}<0.01)$ compared to control and the values were also found higher for the groups $\mathrm{B}$ and $\mathrm{C}$ than that of control.
\end{abstract}

Key words: Fatty acids, haematobiochemical parameters, rat.

\section{INTRODUCTION}

Fat is used in rat feeds mainly for its energy contents and also a source of essential fatty acids. Fat increases energy density and it has a lower heat increment or greater net energy per calorie of metabolized energy. Fat has 2.25 times more energy per unit weight than carbohydrate or protein. Long term consumption of oxidized oils and fats has been reported to cause growth retardation, thrombosis, fatty livers, essential fatty acid deficiency, nucleic acid deficiency and micronutrient malnutrition leading to deactivation of key metabolic enzymes ${ }^{[1,2}$, $3,4,5]$. The free radicals that are generated may be involved in the etiology of diseases such as cancer, diabetes, arthritis, and cataract formation ${ }^{[6,7,8]}$. Lipid circulates in the blood as a complex molecule called lipoproteins. Over $95 \%$ of all the lipids in the plasma are in the form of lipoproteins, which are mixture of triglycerides, cholesterol and phospholipids. Cholesterol is an important metabolic precursor for biosynthesis of steroid hormones. Triglycerides are used for energy production; therefore two-third to three quarter of all the energy derived directly by the cells might be supplied with triglycerides ${ }^{[9]}$. High dietary fat is a risk factor for hypercholesterolemia, atherosclerosis, cardiovascular diseases and obesity. It has been shown that not only the amount of fat consumed but also the type of fatty acid influences the serum cholesterol ${ }^{[10]}$. The ingestion of polyunsaturated fatty acids present in vegetable oils is inversely related to the incidence of heart diseases by decreasing cholesterol and triacylglycerol plasmatic levels ${ }^{[11]}$. It leads to the reduction of cholesterol levels, which is mainly Low Density Lipoprotein (LDL). Information about effect of fatty acid supplementation on haemato biochemical parameters in rat have to be reviewed to learn the mechanism of many diseases in humans. Considering the above idea, the research was to study the effects of different levels of fatty acids supplementation on body weight, to study the effects of fatty acids supplementation on hematological parameters (TLC, DLC, \& PCV) and to study the effects of fatty acids supplementation on biochemical parameters (Blood glucose, SGPT \& Cholesterol).

\section{MATERIALS AND METHODS}

The experiment was carried out in the Department of Physiology, Bangladesh Agricultural University, Mymensingh between $31^{\text {st }}$ August, 2008 and $29^{\text {th }}$ October, 2008.

A total of twenty, 7 weeks old Long Evans rat weighing between 110-115 g that was purchased from Bangabandhu Sheikh Mujib Medical University were used in the experiment. Rats were randomly assigned into four equal groups and numbered as group A, B C and D. Each group was consisting of five rats. Mice groups were housed in separate rectangular metallic case $\left(9 " \times 11^{\prime \prime} \times 7 "\right)$ wrapped with wire mesh and was supported on four metallic legs. Proper hygienic measures and ventilation of the room and rat case was maintained throughout the experimental period. Group A was 
considered as control and fed only with rat pellet. Group B was treated with $20 \mathrm{mg}$ Soybean oil per $\mathrm{kg}$ feed. Group C was treated with $20 \mathrm{mg}$ Mustard oil per $\mathrm{kg}$ feed. Group D was treated with $20 \mathrm{mg}$ Ghee per $\mathrm{kg}$ feed and fed for 60 days. Their body weight was recorded prior to experiment, at $30^{\text {th }}$ day and at $60^{\text {th }}$ day before morning feeding and the average live weight and that of weight gain of rats were calculated separately for each replication.

Table1. Body weight (Means \pm SE) in rats $(n=)$ after treating some selected fatty acids supplementation

\begin{tabular}{|c|c|c|}
\hline Groups of rats & $\begin{array}{c}1^{\text {st }} \text { observation (Prior to } \\
\text { exp.) }\end{array}$ & $2^{\text {nd }}$ observation $\left(30^{\text {th }}\right.$ day $) \quad 3^{\text {rd }}$ observation $\left(60^{\text {th }}\right.$ day $)$ \\
\hline
\end{tabular}

cholesrerol level was determined by Reflotron ${ }^{\circledR}$ autoanalyzer (Boehringer Mannheim, Germany).

For histopathology the liver was collected and preserved in a jar containing $10 \%$ buffered formalin for each group and allowed to be fixed. These formalin fixed livers were processed, sectioned and stained with haematoxylin and eosin $(\mathrm{H} \& \mathrm{E})$ for histopathological study according to Luna ${ }^{[14]}$.

The mean values of the body weight, haematological and biochemical parameters in the different treatment groups were compared with the control by performing F-test for overall significance and lest
$115.00 \pm 2.89$

$115.00 \pm 2.78$

$116.67 \pm 1.67$

$117.00 \pm 1.15$
Group A (Control)

Group B (20 mg Soybean oil//kg feed)

Group C (20 mg Mustard oil/kg feed)

Group D (20 mg Ghee/kg feed)
$132.00 \pm 1.15$

$155.67 \pm 2.33$

$135.33 \pm 0.88$

$158.33 \pm 1.20$

$142.33 \pm 1.45$

$160.00 \pm 2.89$

$152.67 \pm 1.40$

$185.00 \pm 2.76$

Level of significance NS

$* *$

The above values represent the mean \pm standard error (SE) of the body weight of 5 rats

**=Significant at 1 percent level $(\mathrm{P}<0.01)$

NS=Not Significant

For estimation of blood glucose level a small drop of blood was collected directly from the tail of all rats except pregnant rat during the research work and was placed on the glucose strips at automatic ACCUCHEKActive (Glucometer). The reading of blood glucose level from the ACCU-CHEKActive (Glucometer) was carefully observed in the day 0 , day 25 and day 60.

Blood samples were collected at the end of feeding trial directly from heart after opening the abdominal and thoracic cavity by killing the rats after performing general anesthesia using ether. Blood sample was kept in a series of sterile test tubes containing anticoagulant (Double oxalate salt) at a ratio of $1: 10$ and was kept in ice bath till examination. Haematological studies were performed within two hours of blood collection. Total leukocyte count (TLC) was performed as per methods described by Coffin ${ }^{[12]}$. Packed cell volume (PCV) or haematocrit was measured by Wintrobe haematocrit tube as described by Lamberg and Rothstein ${ }^{[13]}$. Differential leukocyte count (DLC) was also done by the procedure described by Lamberg and Rothstein ${ }^{[13]}$.

Biochemical studies ware performed using serum sample prepared from $3 \mathrm{ml}$ of blood in the next morning. Serum Glutamate Pyruvate Transminase (SGPT) / Alanin Amino Transferase(ALT) and total significant difference (lsd) test has also performed to detect best level of fatty acid. MSTAT programs were used to analyze the data.

\section{RESULTS AND DISCUSSION}

The body weights are presented in Table 1 .The mean body weight of group B, C and D of $2^{\text {nd }}$ and $3^{\text {rd }}\left(30^{\text {th }}\right.$ day and $60^{\text {th }}$ day respectively) observation was significantly (P>0.01) higher compared to group A (Control). The result obtained coincide with the finding of Karaji-Bani et al. ${ }^{[15]}$ who studied the effect of $12 \%$ palm oil on 30 days old male rats and found that the mean value of rats weight was increased significantly $(\mathrm{p}<0.05)$ with energy intake in diet .

The heamatological parameters are presented in Table 2. TLC and PCV value of group D increased significantly $(\mathrm{P}<0.01)$ compared to control. The values were also found higher for the group of $\mathrm{B}$ and $\mathrm{C}$ than that of control but it was not significant. The change of DLC values compared to control was significant for none of the supplemented feed groups (B, C and D). These results agreed with Mesembe et al. ${ }^{[16]}$ who observed that the white blood cell count (WBC) of the oil treated group was significantly higher than that of control group. These results are also similar to Ekanem and Yusuf ${ }^{[17]}$ who found that there were significant increased in the haemoglobin $(\mathrm{Hb})$ concentration, packed cell volume (PCV), red blood cell (RBC), white blood cell and platelet counts of oil-treated rats when compared with the 
untreated. TLC count in the present finding is consistant to that of Barek et al. ${ }^{[18]}$ who reported an increased value for soyabean oil treated broiler birds. increase in activities of serum alkaline phosphatase as well as glutamate oxaloacetate and glutamate pyruvate transaminases .

Table3. Effect of some selected fatty acids on

Table2. Effect of some selected fatty acids on hematological

\begin{tabular}{|c|c|c|c|c|c|c|c|}
\hline \multirow{2}{*}{ Groups of rats } & \multicolumn{5}{|c|}{$\operatorname{DLC}(\%)$} & \multirow{2}{*}{\begin{tabular}{|c|} 
TLC \\
$\left(1000 / \mathrm{mm}^{3}\right)$
\end{tabular}} & \multirow{2}{*}{$\begin{array}{c}\mathrm{PCV} \\
(\%)\end{array}$} \\
\hline & Neutrophill & Eosinophill & Basophil & Monocyte & Lymphocyte & & \\
\hline \multirow{2}{*}{ Group A (Control) } & 12.60 & 3.80 & 0.60 & 6.80 & 76.20 & 8.05 & 30.82 \\
\hline & \pm 0.51 & \pm 0.66 & \pm 0.40 & \pm 0.66 & \pm 1.39 & \pm 0.74 & \pm 0.90 \\
\hline Group B(20 mg & 13.40 & 3.20 & 0.40 & 5.60 & 77.40 & 9.71 & 32.40 \\
\hline Soybean oil/kg feed) & \pm 0.51 & \pm 0.58 & \pm 0.24 & \pm 0.40 & \pm 0.75 & \pm 0.61 & \pm 0.82 \\
\hline Group C(20 Mastured & 12.20 & 4.00 & 0.60 & 5.60 & 77.40 & 10.45 & 35.65 \\
\hline oil/kg feed) & \pm 0.73 & \pm 0.45 & \pm 0.40 & \pm 0.40 & \pm 1.21 & \pm 0.29 & \pm 0.75 \\
\hline Group D $(20 \mathrm{mg}$ & 12.00 & 5.00 & 0.40 & 4.40 & 77.60 & 11.43 & 38.43 \\
\hline Ghee/kg feed) & \pm 0.55 & \pm 0.32 & \pm 0.24 & \pm 1.03 & \pm 0.81 & \pm 0.55 & \pm 0.86 \\
\hline Level of significance & NS & NS & NS & NS & NS & $* *$ & $* *$ \\
\hline
\end{tabular}

parameters in rats

The above values represent the mean \pm standard error (SE) of the hematological parameters of 5 rats

$\mathrm{NS}=$ Not significant

$* *=\quad$ Significant at 1 percent level $(\mathrm{P}<0.01)$

The effect of some selected fatty acid on biochemical parameters are presented in Table 3. The blood glucose level of group D was significantly increased $(\mathrm{P}<0.01)$ compared to that of control, the values were also found higher in group $\mathrm{B}$ and $\mathrm{C}$ respectively but the increment was not statistically significant. This result is similar to Zaoui et al. ${ }^{[19]}$ who reported that high level of fixed oil caused hyperglycemia. The serum cholesterol level and serum glutamic pyruvic transaminase (SGPT) of group D increased significantly $(\mathrm{P}<0.01)$ compared to control. These values were also found higher for the group $\mathrm{B}$ and $\mathrm{C}$ than that of control but it was not significant. The present finding agreed with Jeffery et al. ${ }^{[22]}$ who reported that high fat in diet increased the concentration of serum cholesterol.

\begin{tabular}{|c|c|c|c|}
\hline $\begin{array}{l}\text { Groups of } \\
\text { rats }\end{array}$ & $\begin{array}{l}\text { Glucose } \\
(\mathrm{mg} / \mathrm{dl})\end{array}$ & $\begin{array}{l}\text { SGPT } \\
(\mathrm{U} / \mathrm{L})\end{array}$ & $\begin{array}{l}\text { Cholesterol } \\
(\mathrm{mg} / \mathrm{dl})\end{array}$ \\
\hline $\begin{array}{l}\text { Group A } \\
\text { (Control) }\end{array}$ & $4.47 \pm 0.08$ & $\begin{array}{l}21.54 \\
\pm 1.10\end{array}$ & $117.63 \pm 1.68$ \\
\hline $\begin{array}{c}\text { Group B } \\
\text { (20 mg } \\
\text { Soybean oil / } \\
\text { Kg feed) }\end{array}$ & $5.67 \pm 0.09$ & $22.07 \pm 0.97$ & $126.30 \pm 2.79$ \\
\hline $\begin{array}{l}\text { Group C } \\
\text { (20 mg } \\
\text { Mustard oil } \\
\text { / Kg feed) }\end{array}$ & $6.27 \pm 0.12$ & $24.76 \pm 0.45$ & $132.09 \pm 1.25$ \\
\hline $\begin{array}{c}\text { Group D } \\
\text { (20 mg } \\
\text { Ghee / Kg } \\
\text { feed) }\end{array}$ & $6.30 \pm 0.06$ & $25.54 \pm 0.98$ & $149.87 \pm 1.78$ \\
\hline $\begin{array}{c}\text { Level of } \\
\text { significance }\end{array}$ & $* *$ & $* *$ & $* *$ \\
\hline
\end{tabular}

This result is also similar to Ekanem and Yusuf [20] who found that oil-treated diets results significant biochemical parameters in rat

In histopathology study, it was observed that in group B and D slightly swollen hepatocytes and fatty changes occurred in the liver. The fatty degeneration and hepato cellular necrosis were found higher in group D compared to group B. The hepato celullar necrosis with congestion observed in this present study may be due to heavy fat intake in diet. Lipotrophic factors are necessary for removal of fat from liver brought to it by the blood. This food factors absorption was less due to ulceration leads to the rapid accumulation of fat in liver. No such histopathological changes were observed in control group and slightly observed in group $\mathrm{C}$.

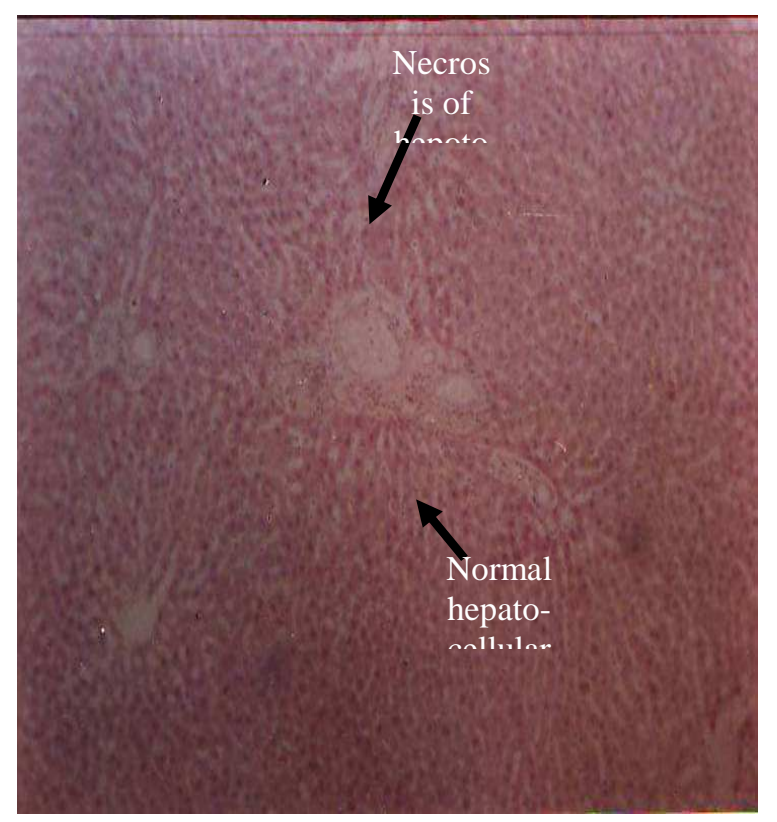

Plate 1. Histopathological section of liver (group A) showing normal $( \pm)$ hepato- cellular degeneration and necrosis (H\&E staining x333)

It can be concluded that animal fat is more injurious to health. But before making any comments, further research could be conducted with a greater number rats and longer duration to observe remarkable changes. 


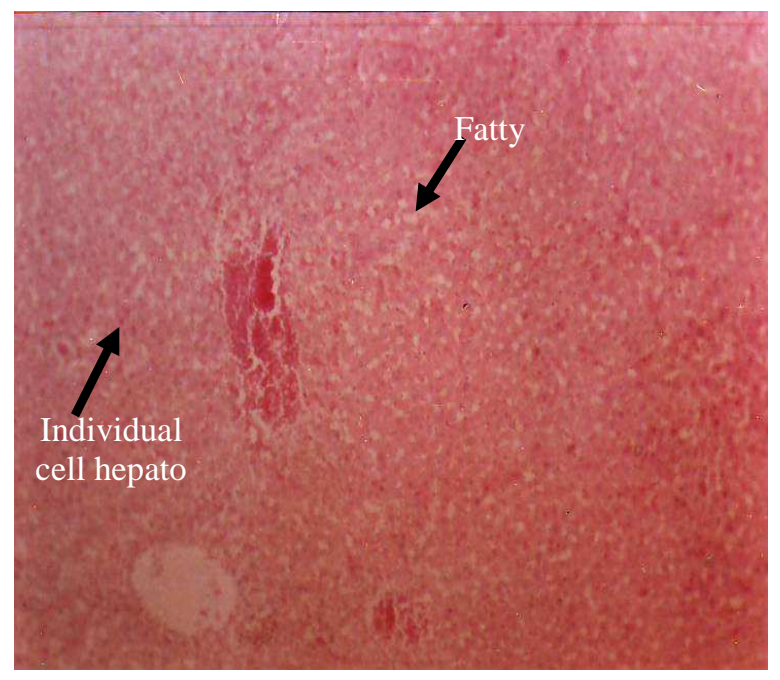

Plate2. Histopathological section of liver (group B) showing fatty degeneration and individual cell hepato cellular necrosis (+) (H\&E staining x333)

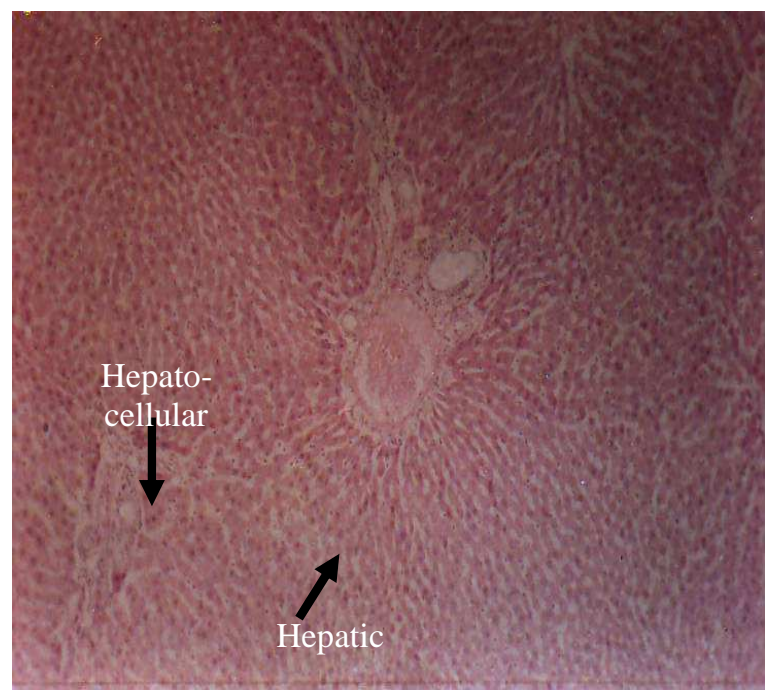

Plate 3. Histopathological section of liver (group C) showing normal $( \pm)$ hepato celular degeneration and necrosis (H\&E staining x333)

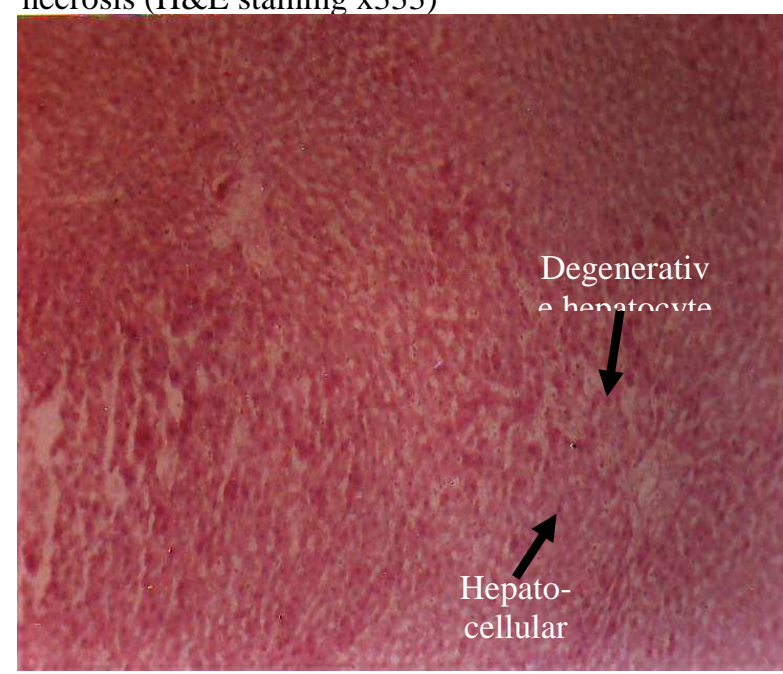

Plate 4. Histopathological section of liver (group D) showing scattered (++) hepato celular necrosis and degeneration of hepatocyte (H\&E staining x333)

\section{REFERENCES}

1. Hill EG, Johnson SB, Lawson LD, Manfouz MM, Holman RT (1982). Perturbation of the metabolism of essential fatty acids by dietary partially hydrogenated vegetable oil. Pro. Natl. Acad. Sci. 79: 953- 957.

2. Izaki Y, Yoshikawa S and Uchiyama M (1984). Effect of ingestion of thermally oxidized frying oil on peroxidative criteria in rats. Lipids 19(5):324 331.

3. Golden MHN and Ramdath D (1987). Nutritional aspects of free radicals. Free Rad. Biol. Med. 46:55-68.

4. Isong EU, Ifon ET, Eka OU, Essien EU and Umoh IB (1992). Effect of intermittently thermoxidized palm oil on normal and malnourished rats. Trop. J. Appld. Sci. 2:118-21.

5. Osim EE, Owu DU, Isong EU and Umoh IB (1992). Influence of Chronic consumption of thermoxidized palm oil diet on platelet aggregation in the rat. Discov. Innov. 48:30-87.

6. Sun Y (1990). Free radicals, antioxidant enzymes and carcinogens. Free Rad. Biol. Med. 8:583-599.

7. Pryor WA (1991). The antioxidant nutrients. What we know, what to find out. Am. J. Clin. Nutr. 53:3915-3935.

8. Lunec H (1992). Oxygen radicals, their measurement and role in major diseases. J. Int. Fed. Clinic. Chem. 14(2): 58-63.

9. Guyton AC (1971). Text Book of Medical Physiology. $11^{\text {th }}$ ed.,Elsevier Inc. Philadelphia, Pennsylvania.Parveen Y, Sherringto EJ and Jeffery NM (1995). Comparison of the effectt of a range of dietary lipids upon serum and tissue lipid composition in rat. Int. J. Biochem. Cell Biol. 27:297.

10. heng X, Avella M and Botham MK (2001). Comparison of the effect of dietary n-3 and n-6 polyunsaturated fatty acids on very-low-density lipoprotein secretion when delivered to hepatocytes in chylomicron reminants. Biochem J. 357: 481-487.

11. Coffin DL (1955). Manual of Veterinary Clinical Pathology. $3^{\text {rd }}$ ed., Coinstock Publishing Associates, Inc. Ithaca, New York. pp. 116-117.

12. Lamberg SL and Rothstein R (1977). Laboratory Manual of Hematology and Urinalysis. $1^{\text {st }}$ ed., Avi Publishing Company, Inc. Westport Connecticut, USA.

13. Luna LG (1968). Manual of Histologic Staining Methods of the Armed Forces Institute of Pathology. $3^{\text {rd }}$ ed., McGraw- Hill Book Co., New York, USA. pp. 258.

14. Karaji-Bani M, Montazeri $\mathrm{F}$ and Hashemi $\mathrm{M}$ (2006). Effect of Palm Oil on Serum Lipid Profile in Rats. Pakistan. J. Nutri. 5 (3): 234-36.

15. Mesembe OE, Ibanga I and Osim EE (2004). The effects of fresh and thermoxidized palm oil diets 
on some haematological indices in the rat. Nigerian J. Physio. Sci. 19(1-2): 86 -91.

17. Ekanem JT and Yusuf OK (2008). Some biochemical and haematological effects of black seed (Nigella sativa) oil on Trypanosoma brucei infected rat. African J. Biotech. 7 (2): 153-157.

18. Barek MA, Ahmad N, Majumder S, Islam K and Islam R (2003). Hemato-biochemical parameters and performances of broiler feed with soybean oil and protein supplementation. Bangl. J. Anim.Sci. 32 (1): 131-138.
19.Zaoui A, Cherrah Y, Alaoui K, Mahassine N, Amarouch H and Hassar M (2002). Effects of Nigella sativa fixed oil on blood homeostasis in rat. J. Ethnopharmacol. 79(1): 23-26.

20. Jeffery NMP, Yaqoob EA, Kewsholme PC and Calder (1996). The Effects of olive oil upon rat serum lipid levels and lymphocyte functions appear to be due to oleic acid. Ann. Nutr. Metab. 40:71-80. 